\title{
Pengaruh Kompetensi Terhadap Pengembangan Karir dan Kinerja Guru di Kota Jember
}

\author{
Roro Aditya Novi Wardhani, ${ }^{* 1}$ dan Shendy Andrie Wijaya ${ }^{2}$ \\ Program Studi Pendidikan Ekonomi \\ IKIP PGRI Jember \\ Jember, Indonesia
}

e-mail: adityawardhani511@gmail.com¹, andrie69.aw@gmail.com²

Riwayat Artikel Tanggal diajukan: 9 Mei 2020

Tanggal diterima : 6 Juni 2020

Tanggal dipublikasikan: 29 Juni 2020
Pengutipan: Wardhani, R. A.N \& Wijaya, S. A. (2020). Pengembangan Pengaruh Kompetensi Terhadap Pengembangan Karir dan Kinerja Guru di Kota Jember. Jurnal Pendidikan Ekonomi Undiksha, 12 (1), 148-156

\begin{abstract}
Abstrak
Tujuan penelitian adalah untuk menganalisis dan menguji apakah kompetensi memiliki pengaruh terhadap pengembangan karir dan kinerja guru. Penelitian dilakukan di semua SMAN yang ada di kota Jember. Variabel yang digunakan dalam penelitian ini terdiri dari kompetensi, pengembangan karir dan kinerja guru. Jenisnya penelitian menggunakan pendekatan kuantitatif dengan metode explanatory research. Populasinya adalah semua guru ekonomi di SMA Negeri Kota Jember. Metode penentuan sampel memakai metode purposive sampling dengan kriteria adalah guru tetap yang sudah bekerja minimal 2 tahun dengan jumlah sebanyak 30. Metode analisis data menggunakan analisis jalur. Setelah dianalisa, maka hasil uji $\mathrm{t}$ dan analisis jalur, dapat diketahui bahwa kompetensi memiliki pengaruh pada pengembangan karir dan kinerja guru. Hasil analisis juga mengindikasikan bahwa pengembangan karir mampu memediasi kompetensi terhadap kinerja guru. Seorang guru yang telah memiliki kompetensi, akan dengan mudahnya untuk mengembangkan karir yang mana akan berdampak pada kinerjanya. Guru yang profesional, akan selalu memiliki tuntutan tinggi dalam pekerjaan, karenanya dengan kompetensi dan pengembangan karir yang bagus, maka kinerjanya juga akan semakin bagus
\end{abstract}

Kata kunci: kinerja; kompetensi, pengembangan karir

\begin{abstract}
The purpose of this study is to analyze the role of career development in influencing competence on teacher performance. The study was conducted in all the high schools in Jember. The variables used in this study consisted of competence, career development and teacher performance. The type of research is a quantitative approach research with explanatory research methods. The population is all economics teachers in Jember City Public High School. The method used to determine the sample is purposive sampling with the criteria of permanent teachers who have worked for 2 years at a minimum. Data analysis method uses path analysis. After being analyzed, the results of the $t$ test and path analysis, can be seen that competence has a significant effect on teacher career development and teacher performance. The analysis also shows that career development is able to mediate competence in teacher performance. A teacher who has competence, it will be easy to develop a career which will have an impact on performance. Professional teachers, will always have high demands in their work, so with competence and good career development, the performance will also be better.
\end{abstract}

Keywords : performance; competence, career development 


\section{PENDAHULUAN}

Peranan guru di era milenial saat ini sangatlah penting, karena mereka diharapkan dapat meningkatkan kualitas pendidikan formal dan non formal di Indonesia. Guru juga diharapkan bisa menghasilkan dan mencetak generasi muda baru yang mumpuni di bidangnya. Tantangan guru di era milenial ini sangat besar, mereka berhadapan dengan siswa yang jelas berbeda pola pikir dan pandangnya dengan generasi sebelumnya. Tantangan menaklukan siswa di generasi milenial menjadi pekerjaan rumah guru untuk bisa mengasah kemampuannya semakin baik lagi.

Guru merupakan tenaga pendidik yang punya misi utama mulia yaitu mengajar, mendidik, mengarahkan, membimbing, menilai dan mengevaluasi siswanya. Guru dituntut bisa menyelenggarakan proses pendidikan sebaik mungkin, dalam upaya pembangunan pendidikan di Indonesia. Hal ini menjadi penting karena jaman terus berkembang dan kurikulum terus update mengikuti perkembangan. Terutama di era industrialisasi 4.0, kualitas pendidikan di Indonesia harus terus ditingkatkan. Semua bisa terwujud jika segala pihak saling bersinergi mewujudkannya. Dan kunci utamanya adalah guru, didukung oleh sekolah, orang tua dan pemerintah.

Mengutip Undang-Undang No. 14 tahun 2005 tentang Guru dan Dosen Pasal 4, menyatakan secara garis besar bahwa guru merupakan agen pembelajaran yang memiliki fungsi meningkatkan mutu pendidikan nasional, yang mana agar guru tersebut dapat melaksanakan fungsinya dengan baik, maka mereka wajib memiliki kompetensi. Kompetensi yang harus dipunyai seorang guru pada dasarnya ada empat, yaitu kompetensi pedagogik; kompetensi profesional; kompetensi sosial; dan kompetensi pribadi (Peraturan Pemerintah (PP) N. 19 Tahun 2005). Guru harus punya keempat kompetensi tersebut, karena kompetensi itu saling menunjang.

Guru tidak mungkin dan tidak boleh lebih condong pada salah satu kompetensi, mereka harus menguasai semua kompetensi tersebut. Ketika guru telah menguasai keempat kompetensi tersebut, maka akan membantu mereka dalam menghasilkan proses pembelajaran yang sesuai, berkualitas dan menyenangkan. Karena guru dan siswa adalah dua pihak yang saling berinteraksi. Guru dapat menciptakan suasana kelas yang menyenangkan jika mampu menguasai diri, siswa dan situasi. Komunikasi yang baik juga menunjang terjadinya proses pembelajaran yang efektif.

Mengutip pernyataan Saud (2009:44), bahwa kompetensi merujuk pada tindakan atau kinerja rasional yang dapat digunakan untuk mencapai tujuannya berdasarkan prasyarat yang diajukan. Guru sebagai pendidik dituntut punya kemampuan dalam menjalankan tugas dan tanggungjawabnya, karenanya guru patut untuk menguasai bahan pembelajaran, cara mengajar dan kepribadian yang kokoh sebagai dasar kompetensi. Jika guru tidak memiliki itu semua, maka guru tersebut mengalami kegagalan dalam menjalankan tugas tanggungjawabnya.

Guru adalah kunci utama berhasilnya proses pembelajaran. Kualitas kompetensi seorang guru memegang peranan penting agar dapat menciptakan kualitas terbaik pada proses pembelajarannya, serta mampu mengindikasikan dan menjadi atribut diri seorang guru yang profesional sesuai bidang dan menyumbangkan kontribusinya untuk meningkatkan kinerja pembelajaran.

Kinerja pembelajaran guru-guru perlu ditingkatkan, terutama pada guru-guru Ekonomi di SMA Negeri Jember. Persaingan sekolah semakin ketat, walaupun sekarang persaingan terhapus oleh sistem jarak sekolah, tetapi semua sekolah harus tetap berlomba dalam kualitas pembelajaran, output dan outcome siswa yang bermutu demi berlangsungnya sekolah. Jember merupakan salah satu kota di Jawa Timur yang banyak sekolah menengah atasnya. Agar dapat bersaing tidak hanya ditingkat lokal, maka harus didukung oleh sarana dan prasarana dengan dijalankan oleh SDM yang berkompeten. Salah satunya adalah guru yang memiliki kompetensi. Diharapkan guru-guru juga mulai bisa meningkatkan jenjang pendidikannya demi meningkatkan karir dan kompetensinya. 
Kompetensi yang dipunyai oleh seorang guru sangat dapat menunjang karirnya. Karir dapat berkembang dengan baik, sehingga kinerjapun akan semakin profesional. Pengembangan karir adalah suatu kegiatan yang dilaksanakan untuk membantu seorang pegawai dalam upaya mengembangkan dirinya secara maksimum dengan cara memplaningkan karir masa depannya di organisasi (Mangkunegara, 2004:45). Karenanya seorang guru yang memiliki keinginan untuk mengembangkan karir, harus bekerja secara maksimal. Pekerjaan tersebut terkait dengan kompetensi yang dipunyainya. Sekolah sebagai tempat guru bernaung, harus senantiasa memantau, membantu dan mendukung guru yang ingin mengembangkan karirnya. Secara garis besar, Mulyasa (2013:63) menyampaikan bahwa kompetensi adalah perilaku masuk akal dalam mencapai tujuan yang dipersyaratkan berdasarkan kondisi yang diimpikan. Kompetensi itu dapat dilihat bentuknya dalam tindakan keseharian saat melaksanakan tugas dan interaksi dengan lingkungan (Antonious, 2015:115, dalam Ayuningtyas, 2013) Pengembangan karir pada guru bisa dilakukan dengan kegiatan penugasan, menaikkan pangkat dan promosi. Upaya pengembangan karir pada guru harus bisa selaras dengan jafung guru tersebut. Pengembangan karir dan profesi ditujukan agar bisa meningkatkan kinerja guru dalam rangka menciptakan proses pembelajaran dan pendidikan dalam dan luar kelas.

Menurut Hasan (2017), karir guru ada 2 jenis, yaitu karir struktural yang berkaitan dengan kedudukan dalam struktural sekolah dan karir fungsional yang berkaitan dengan pencapaian formal dalam profesinya. Kualifikasi dan pengembangan karir guru ditujukan untuk meningkatkan produktivitas guru, mengembangkan keyakinan dan nilai, keterampilan, minat dan bakat sepanjang hayat.

Peningkatan kompetensi dan profesionalitas guru harus bisa seiringan dengan usaha memberikan penghargaan, meningkatkan kesejahteraan, dan perlindungan terhadap guru. Usaha yang dilakukan ini akan menjadi bagian integral dari pengembangan keprofesian guru secara kontinu.

Secara garis besar menurut Hasan (2017), pengembangan karir adalah yang sangat penting bagi para guru karena akan memberi dampak bagi kepuasan kerja terutama kinerja dan peningkatan kesejahteraan. Artinya, jika karir seorang guru itu meningkat, maka akan ada pengakuan dari lembaga yang tempat dia bernaung seperti kenaikan gaji yang diterimanya, tentulah ini akan meningkatkan rasa senang dan nyamannya dalam bekerja. Guru harus memahami bahwa pencapaian tersebut terkait dengan tingkatan karir dan efek dari kenaikan tingkat tersebut.

Pengembangan karir menjadi sangat penting bagi para guru dalam proses peningkatan kinerja. Penilaian Baik ataupun buruknya kinerja guru bisa terlihat pada keahlian melaksanakan dan menyelesaikan tugas pekerjaannya sesuai dengan yang ditanggungjawabkan kepadanya. Menurut Hasan (2017), Penilaian kinerja (PK) adalah aktivitas yang dilaksanakan untuk merupakan kegiatan yang dilakukan untuk mengukur sukses dan tidaknya guru saat melakukan proses pendidikan dan pengajaran sesuai dengan standar tolak ukurnya.

Banyak penelitian terkait kompetensi, pengembangan karir dan kinerja guru telah dilakukan. Diantaranya adalah, Padendean (2017), yang dalam penelitiannya menemukan bahwa kompetensi memiliki pengaruh pada pengembangan karir. Wasono (2019), dalam penelitiannya mendapatkan bahwa kompetensi guru memiliki pengaruh pada pengembangan karir guru. Zuzandi dan Sudarwan (2019), dalam penelitiannya menemukan bahwa kompetensi guru dapat ditingkatkan dengan mengikuti pelatihan yang mana hal tersebut dilakukan untuk mengembangkan karirnya disekolah. Muin (2017) mendapati bahwa kompetensi guru memiliki pengaruh pada kinerja guru SMAN di Kabupaten GOWA. Roro (2017) juga mendapatkan hasil bahwa kompetensi guru memiliki pengaruh pada kinerja guru ekonomi SMA Negeri Di Kota Bandung. Distyawati (2017) mendapatkan hasil bahwa pengembangan karir memiliki pengaruh pada kinerja. Ni'mah (2018), juga 
menemukan bahwa pengembangan karir memiliki pengaruh pada kinerja.

Berdasarkan pemaparan di atas, maka tujuan penelitian adalah untuk menganalisis pengaruh kompetensi terhadap pengembangan karir dan kinerja guru ekonomi di SMA Negeri di Jember, dan menganalisis peran pengembangan karir dalam memengaruhi kompetensi terhadap kinerja guru.

\section{METODE}

Pendekatan penelitian adalah dengan metode explanatory researh. Populasinya adalah semua guru ekonomi SMA Negeri di Jember. Sampel terkumpul dengan pendekatan purposive sampling, yaitu penentuan sampel dengan kriteria guru Ekonomi SMA Negeri Di Kota Jember yang telah bekerja minimal 2 tahun dan telah menjadi guru tetap. Sampel penelitian terkumpul sebanyak 30 . Kuesioner merupakan data primer yang didapatkan dengan disebarkan kepada responden, dan data sekunder yang didapat dari website berupa perkembangan SMAN di Jember. Variabel yang digunakan dalam penelitian ini terdiri dari kompetensi (X), Pengembangan karir $\left(Y_{1}\right)$ dan Kinerja $\left(Y_{2}\right)$.

Hipotesis dalam penelitian ini ada 4, yaitu: kompetensi memiliki pengaruh pada pengembangan karir guru $\left(\mathrm{H}_{\mathrm{a} 1}\right)$, kompetensi memiliki pengaruh pada kinerja guru $\left(\mathrm{H}_{\mathrm{a} 2}\right)$, pengembangan karir memiliki pengaruh pada kinerja guru $\left(\mathrm{H}_{\mathrm{a} 3}\right)$, dan pengembangan karir dapat memediasi pengaruh kompetensi terhadap kinerja guru $\left(\mathrm{H}_{4}\right)$. Metode analisis jalur dipakai untuk pembuktian hipotesis yang telah diajukan, dengan persamaan

$Y_{1}=\beta X$

$Y_{2}=\beta X+\beta Y_{1}$

Dimana :

$X=$ Kompetensi

$\mathrm{Y}_{1}=$ pengembangan karir

$\mathrm{Y}_{2}=$ kinerja

\section{HASIL DAN PEMBAHASAN}

Pengujian instrumen dilakukan dengan uji validitas dan reliabilitas pada ketiga variabel yaitu kompetensi, pengembangan karir dan kinerja guru, dengan hasil perhitungan sebagai berikut:

Tabel 1. Rekapitulasi Hasil Uji Validitas

\begin{tabular}{lllll}
\hline Variabel & Indikator & $\begin{array}{l}\text { Pearson } \\
\text { Correlation }\end{array}$ & Sig & Keputusan Validitas $>0,30$ \\
\hline \multirow{3}{*}{ Kompetensi $(\mathrm{X})$} & 1 & 0,716 & 0,000 & Valid \\
& 2 & 0,735 & 0,000 & Valid \\
& 3 & 0,727 & 0,000 & Valid \\
Pengembangan & 4 & 0,748 & 0,000 & Valid \\
Karir $\left(\mathrm{Y}_{1}\right)$ & 2 & 0,755 & 0,000 & Valid \\
& 3 & 0,728 & 0,000 & Valid \\
& 4 & 0,719 & 0,000 & Valid \\
& 5 & 0,758 & 0,000 & Valid \\
& 1 & 0,715 & 0,000 & Valid \\
Kinerja $\left(\mathrm{Y}_{2}\right)$ & 2 & 0,764 & 0,000 & Valid \\
& 3 & 0,753 & 0,000 & Valid \\
& 4 & 0,742 & 0,000 & Valid \\
& 5 & 0,733 & 0,000 & Valid \\
& 6 & 0,729 & 0,000 & Valid \\
& 7 & 0,712 & 0,000 & Valid \\
& 1 & 0,833 & 0,000 & Valid \\
\hline
\end{tabular}

Sumber: Data diolah, 2020

Hasil uji validitas, memperlihatkan jika semua butir pertanyaan kueioner berstatus valid, karena masing-masing indikator memiliki nilai pearson correlation $>0,30$ dan nilai signifikansi $<0,05$, sehingga semua skor indikator-indikator bisa memberikan representasi yang baik dan dapat digunakan sebagai instrument dalam 
Tabel 2. Rekapitulasi Hasil Uji Reliabilitas

\begin{tabular}{lll}
\hline Variabel & cronbach's alpha & Keputusan \\
\hline Kompetensi $(\mathrm{X})$ & 0,831 & Reliabel \\
Pengembangan karir $\left(\mathrm{Y}_{1}\right)$ & 0,812 & Reliabel \\
Kinerja $\left(\mathrm{Y}_{2}\right)$ & 0,806 & Reliabel \\
\hline
\end{tabular}

Sumber: Data diolah, 2020.

Hasil uji reliabilitas pada Tabel 2, menunjukan bahwa pada masing-masing variabel menunjukan bahwa nilai cronbach's alpha diatas nilai $\alpha>0,60$, jadi instrumen dinyatakan reliabel semua. Dengan kata lain instrument layak dan dapat digunakan. Setelah dinyatakan valid dan reliabel, maka selanjutnya adalah uji hipotesis. Hasil uji memakai batas signifikansi sebesar 0,05 untuk melihat pengaruh langsung antar variabel.

Tabel 3. Rekapitulasi Hasil Pengujian Hipotesis

\begin{tabular}{llll}
\hline Variabel & Koef. $\beta$ & Signifikansi & Keputusan \\
\hline Dependent: & & & \\
$Y_{1}:$ Pengembangan karir & 0,312 & 0,021 & Berpengaruh signifikan \\
Independent: & & & \\
$\quad \mathrm{X}:$ Kompetensi & & & \\
Dependent: & & & \\
$Y_{2}:$ Kinerja & & & \\
Independent: & 0,297 & 0,013 & Berpengaruh signifikan \\
$X$ : Kompetensi & 0,303 & 0,025 & Berpengaruh signifikan \\
$Y_{2}:$ Pengembangan karir & & & \\
\hline
\end{tabular}

Sumber: Data diolah, 2020.

Setelah dilakukan analisis, maka nampak hasilnya yaitu semua hipotesis yang telah diajukan, dapat diterima. Hasil analisis memperlihatkan bahwa pada persamaan 1, kompetensi mempunyai pengaruh pada pengembangan karir karena nilai signifikansinya adalah $0,021<0,05$; pada persamaan 2 , kompetensi mempunyai pengaruh signifikan terhadap kinerja karena nilai signifikansinya $0,013<0,05$; dan pengembangan karir mempunyai pengaruh pada kinerja karena nilai signifikansinya $0,025<0,05$. Kompetensi memiliki pengaruh terhadap pengembangan karir dan kinerja guru. Selanjutnya, pengembangan karir dapat memediasi pengaruh kompetensi terhadap kinerja guru di SMA Negeri yang ada di Jember.

Analisis jalur dilakukan untuk menganalisis apakah pengembangan karir mampu menjadi mediasi dalam memengaruhi kompetensi terhadap kinerja guru ekonomi SMA Negeri Di Kota Jember. Jika di dalam analisis jalur terdapat variabel yang tidak memiliki pengaruh, maka variabel tersebut harus di hilangkan sesuai ketentuan trimming theory. Karena hasil analisis mengindikasikan semuanya signifikan, maka tidak perlu dihilangkan. Berikut disajikan gambar koefisien jalur dari persamaan yang telah dibuat: 


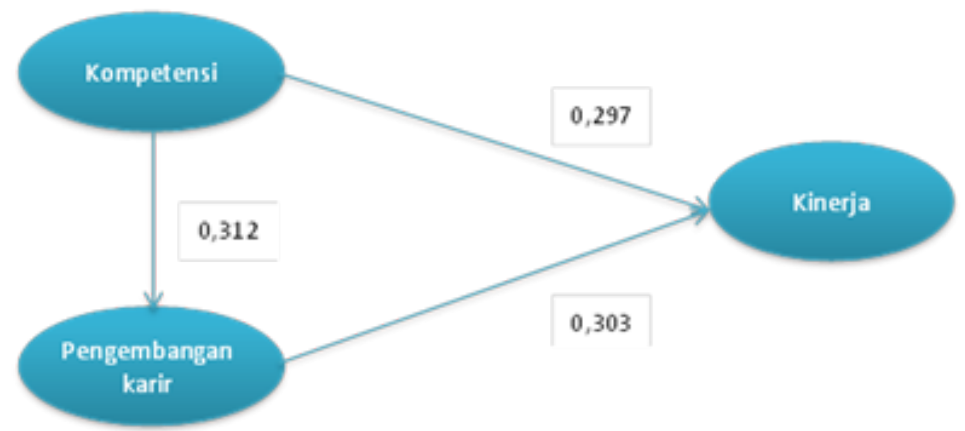

Gambar 1. Hasil Pengaplikasian Persamaan Sumber: Data diolah. 2020.

Persamaan jalur dari gambar 1 dapat dituangkan sebagai berikut:

$\mathrm{Y} 1=\beta_{0}+0,312$

$Y 2=\beta_{0}+0,3297+0,303$ (persamaan 1) (persamaan 2) 
Dalam penelitian ini nampak bahwa kompetensi dapat memengaruhi pengembangan karir dan kinerja guru yang menjadi sampel penelitian. Semua hipotesis yang diajukan diterima. Hasil analisis juga mengindikasikan bahwa pengembangan karir dapat memediasi pengaruh kompetensi pada kinerja guru ekonomi SMA Negeri Di Kota Jember.

Kompetensi memiliki pengaruh signifikan secara langsung terhadap pengembangan karir $(0,021<0,05)$. Hasil analisis mengindikasikan bahwa hipotesis pertama yang berbunyi bahwa kompetensi memiliki pengaruh terhadap pengembangan karir guru diterima. Semakin meningkat kompetensi yang dipunyai oleh guru, maka pengembangan karirnya akan semakin baik. Secara garis besar, kompetensi menurut Sudarmanto (2009:45), merupakan atribut yang dilekatkan pada sumber daya manusia yang unggul dan berkualitas. Atribut yang dimaksud oleh Sudarmanato adalah kualitas yang melekat pada orang atau benda yang merujuk pada karakteristik tertentu untuk melakukan pekerjaan secara efektif. Atribut itu antara lain terdiri dari keahlian, pengetahuan dan keterampilan atau karakteristik tertentu.

Penelitian ini membuktikan bahwa mayoritas guru Ekonomi SMAN Di Kota Jember mepunyai kompetensi. Guru-guru tersebut telah mampu memahami siswanya, mampu merancang, melakukan pembelajaran, mengevaluasi hasil belajar dan mengembangkan potensi yang dimiliki siswa. Guru-guru ekonomi SMA Negeri Di Kota Jember juga sudah punya pribadi yang baik, berakhlak mulia, stabil, berwibawa, arif dan menjadi tauladan bagi siswanya. Selain itu para guru sudah bisa menguasai materi pembelajaran secara mendalam mencakup materi dalam kurikulum, substansi keilmuan yang melekat pada materinya serta menguasai struktur dan metodologi keilmuannya. Pada akhirnya seluruh kompetensi yang melekat pada guru akan menunjang dan mengembangkan karirnya. Penelitian ini sejalan dengan penelitian yang dilakukan oleh Padendean (2017), yang dalam penelitiannya mengindikasikan bahwa kompetensi memiliki pengaruh pada pengembangan karir. Wasono (2019), dalam penelitiannya juga menemukan bahwa kompetensi guru memiliki pengaruh positif signifikan terhadap pengembangan karir guru. Zuzandi dan Sudarwan (2019), dalam penelitiannya menemukan bahwa kompetensi guru dapat ditingkatkan dengan mengikuti pelatihan yang mana hal tersebut dilakukan untuk mengembangkan karirnya disekolah.

Kompetensi guru juga memiliki pengaruh pada kinerja guru. Hipotesis kedua, dapat diterima. Semakin baik kompetensi yang dipunyai oleh guru-guru, maka kinerja juga akan semakin baik. Mengutip pernyataan Sagala (2013) bahwa kompetensi profesional diganti kompetensi bidang studi. Guru harus diberi kepercayaan untuk melakukan proses pembelajaran yang baik, diberikan dorongan dan suasana yang kondusif agar dapat menemukan metode mengembangkan proses pembelajaran yang sesuai dengan kemampuannya dan perubahan era. Terutama di era milenium ini. Seluruh kompetensi yang telah dipunyai oleh guru-guru ekonomi SMA Negeri Di Kota Jember dapat mempermudah guru untuk merencanakan apa yang akan dibawakan saat mengajar, memahami dan menguasai dengan mendalam materi yang akan dibawakan, menguasai akan metode serta strategi mengajar, memberikan tugas dengan mudah pada siswanya, mengelola kelas dengan baik dan bisa melakukan evaluation dan memberi nilai. Hasil penelitian sejalan dengan penelitian yang dilakukan oleh Muin (2017), dimana dia menemukan bahwa kompetensi guru memiliki pengaruh pada kinerja guru SMAN di Kabupaten GOWA. Roro (2017) juga menemukan bahwa kompetensi guru memiliki pengaruh pada kinerja guru.

Hasil analisis mengindikasikan jika pengembangan karir guru memiliki pengaruh pada kinerja. Semakin baik upaya yang dilakukan oleh guru untuk mengembangkan karirnya, maka kinerja juga akan semakin baik. Pekerjaan guru tidak hanya berhenti di pengembangan karir saja, karena kinerja yang bagus, maka karir akan berkembang, setelah itu kinerjapun diharapkan semakin baik karena bukan berarti berhenti saja setelah pengembangan karir. Hipotesis ketiga, diterima dalam penelitian ini. Pengembangan karirpun 
mampu memediasi kompetensi kepada kinerja. Hipotesis empat yang menyatakan bahwa pengembangan karir mampu memediasi kompetensi guru dan kinerja, diterima. Guru-guru dapat melakukan pelatihan untuk semakin meningkatkan karirnya, disamping menguasai empat kompetensi tersebut. Mengutip pernyataan Wahyudi (2012), bahwa guru profesional merupakan guru yang memiliki kemampuan untuk mengelola dirinya sendiri dalam menjalankan tugasnya sehari-hari dalam berproses bergerak dari ketidaktahuan menjadi tahu. Penelitian ini mendukung penelitian Distyawati (2017) yang menemukan bahwa pengembangan karir memiliki pengaruh pada kinerja. Ni'mah (2018), juga menemukan bahwa pengembangan karir memiliki pengaruh pada kinerja.

\section{SIMPULAN DAN SARAN}

Penelitian ini secara keseluruhan telah berhasil membuktikan kajian teori, menerima semua hipotesis yang telah diajukan, dan menjawab semua rumusan masalah, yaitu bahwa bahwa kompetensi memiliki pengaruh pada pengembangan karir, kompetensi memiliki pengaruh pada kinerja guru, pengembangan karir memiliki pengaruh pada kinerja dan pengembangan karir mampu memediasi kompetensi dan kinerja guru ekonomi di SMA Negeri Jember. Berkembangnya kurikulum, memaksa guru untuk senantiasa meningkatkan kompetensinya dan mengembangkan karirnya, agar kinerja semakin baik. Tanggungjawab guru tidak hanya sebatas membacakan teori saja, tetapi juga pada hasil output yang terbaik.

Berdasarkan simpulan ada beberapa saran yang dapat diajukan untuk guru-guru, diantaranya adalah meningkatkan kemampuan guru dibidang IPTEK, untuk mengikuti perkembangan kurikulum. Guruguru juga diharapkan dapat meningkatkan jenjang pendidikan ke yang lebih tinggi untuk dapat menunjang pengembangan karirnya. Terakhir, sekolah harus terlibat penuh dalam memantau dan membantu meningkatkan kompetensi dan pengembangan karir guru, agar apa yang menjadi visi dan misi sekolah dapat terwujud.

\section{DAFTAR PUSTAKA}

Ayuningtyas, D., Pusparahaju, A., \& Ibrahim, S. (2013). KAJIAN TEORI A. Penelitian Terdahulu yang Relevan Penelitian tentang pengembangan karir dapat dibagi dalam dua model , yakni model pengembangan karir berdasarkan Peraturan Pemerintah No . 100 Tahun 2000 dan berdasarkan analisis jabatan. Model pengembang. 11-36.

Distyawaty, D. (2017). Pengaruh Kompetensi Dan Pengembangan Karir Terhadap Kinerja Aparatur Pengawas Inspektorat Daerah Provinsi Sulawesi Tengah. Katalogis, 5(4), 56-68.

Hasan, Z. (2017). Upaya Pengembangan Karir Guru Melalui Peningkatan Kualifikasi Akademik Dan Profesionalisme (Studi Pada Guru Guru SMP Di Kabupaten Bengkalis). Jurnal Akademika. 13(2), 129-137.

Mangkunegara, A.A Anwar Prabu. (2004). Manajemen Sumber Daya Manusia. Bandung: Remaja Rosda Karya

Muin, M. (2017). Pengaruh Faktor Produksi Terhadap Hasil Produksi Merica di Desa Era Baru Kecamatan Tellulimpoe Kabupaten Sinjai. Jurnal Economix, 5(1), 203-214.

Mulyasa. (2013). Pengembangan dan Implementasi Kurikulum 2013. Bandung: PT Remaja Rosdakarya

Ni'mah, Uliy. (2018). Pengaruh Pengembangan Karier Terhadap Kinerja Guru Disdit Bina Insan Kamil Sidareja. Tesis (tidak diterbitkan) IAIN Purwokerto.

Padendenan, Y. (2018). Pengaruh Kompetensi Dan Pengembangan Karir Terhadap Kinerja Pegawai Pada Dinas Pendidikan Dan Kebudayaan Kabupaten Sigi. Katalogis, 5(12). https://doi.org/10.22487/J23022019,2 017.V5.I12.9796

Peraturan Pemerintah (PP) N. 19 Tahun 2005

Roro Suci Nurdianti, R. (2017). Pegaruh Kompetensi Profesional dan Kompetensi Pedagogik Terhadap Kinerja Guru Ekonomi SMA Negeri di Kota Bandung. Jurnal Ilmiah Manajemen \& Bisnis, 18(2), 177-188. 
Rusman. (2012). Model-Model Pembelajaran: Mengembangkan Profesionalisme Guru. Jakarta: PT Raja Grafindo Persada.

Saud, Udin Syaefuddin. (2009). Pengembangan Profesi Guru. Bandung: Alfabeta.

Undang-Undang Republik Indonesia Nomor 14 tahun 2005 tentang Guru dan Dosen.

Wahyudi, I. (2012), Pengembangan Pendidikan, Strategi Inovatif \& Kreatif Dalam Mengelola Pendidikan Secara Konprehensif, PT. Prestasi, Jakarta

Wasono, M. P. J. (2019). Pengaruh peran kepala sekolah dan kompetensi profesional terhadap pengembangan karir guru SMP negeri. Jurnal IImiah Kependidikan, 2(2), 90-107.

Zuzandi. (2019). Pengembangan Profesi Dan Karir Guru. IImiah Manajemen Pendidik, 13(2), 88-99. https://ejournal.unib.ac.id/index.php/m anajerpendidikan/article/view/7287/36 49 